\title{
Erratum to: The impact of incorrect examples on learning fractions: a field experiment with 6th grade students
}

\section{Tim Heemsoth • Aiso Heinze}

\section{Erratum to: Instr Sci \\ DOI 10.1007/s11251-013-9302-5}

Figure 2 has been published incorrectly in the original publication. The corrected figure is provided below.

The online version of the original article can be found under doi:10.1007/s11251-013-9302-5.

T. Heemsoth $(\bowtie) \cdot$ A. Heinze

Leibniz Institute for Science and Mathematics Education, Olshausenstraße 62, 24118 Kiel, Germany e-mail: heemsoth@ipn.uni-kiel.de
A. Heinze
e-mail: heinze@ipn.uni-kiel.de 


\begin{tabular}{|c|c|}
\hline Tom's solution: & Tom's solution: \\
\hline $2-\frac{1}{4}=1 \frac{3}{4}$ & $\frac{1}{4} \cdot 2=\frac{1 \cdot 2}{4}=\frac{2}{4}=\frac{1}{2}$ \\
\hline $\begin{array}{l}\text { There is still } 1 \frac{3}{4} \text { liter in the } \\
\text { bottle. }\end{array}$ & $\begin{array}{l}\text { Petra drinks half a liter. Thus, } \\
\text { there is still } 1 \frac{1}{2} \text { liter in the } \\
\text { bottle. }\end{array}$ \\
\hline $\begin{array}{l}\text { 1) Which solution step is not correct } \\
\text { and why? }\end{array}$ & $\begin{array}{l}\text { 1) Describe the student's solution. } \\
\text { 2) Why is the solution correct? }\end{array}$ \\
\hline $\begin{array}{l}\text { 2) Why do you think the student made } \\
\text { exactly this error? } \\
\text { 3) Solve the problem correctly. }\end{array}$ & $\begin{array}{l}\text { 3) Solve the following problem: Peter } \\
\text { drinks one third of a } 2 \text {-liter bottle of } \\
\text { lemonade. How much is still in the } \\
\text { bottle? Give your results in liters. }\end{array}$ \\
\hline
\end{tabular}

Fig. 2 Exercise example used for the intervention: incorrect condition (left) and correct condition (right) 